\title{
Transferência de conhecimento \\ e suas armadilhas na extensão universitária brasileira
}

\author{
Lais Silveira Fraga
}

Resumo: A ideia de transferência de conhecimento sempre esteve presente na relação entre universidade e sociedade. A noção de que a universidade deveria oferecer às classes populares o conhecimento que produz está na origem do termo extensão e segue presente em toda a sua trajetória histórica. Este artigo tem como objetivo explorar a relação entre extensão e transferência de conhecimento a partir da análise das influências internacionais na extensão universitária brasileira. A literatura sobre extensão no Brasil reconhece duas influências internacionais na prática extensionista no país: as Universidades Populares europeias e os Land Grant Colleges dos EUA. A essas duas influências soma-se o movimento reformista de Córdoba como marco da origem da extensão no Brasil. Inicialmente são abordadas as três influências internacionais na extensão universitária no Brasil e a maneira como a ideia de transferência de conhecimento aparece em cada uma delas. Em seguida, apresenta-se a crítica à ideia de transferência de conhecimento a partir de dois autores referência para a extensão universitária brasileira: Paulo Freire e Michel Thiollent. Por fim, na última seção, analisa-se as três influências diante da crítica à ideia de transferência de conhecimento. Os resultados apresentados sugerem que as influências europeia e dos EUA têm como fundamento a perspectiva da transferência de conhecimento. As universidades populares latino-americanas, por sua vez, parecem apontar para a autocrítica da universidade e para a superação de uma extensão que fomenta uma relação de tutela entre universidade e as classes populares.

Palavras-chave: Extensão universitária. Transferência de conhecimento. Reforma de Córdoba.

\section{Transfer of knowledge and their traps in the Brazilian university extension}

Abstract: The idea of knowledge transfer has always been present in the relationship between university and society. The notion that the university should offer the popular classes the knowledge it produces is at the origin of the term extension and follow this throughout their historical trajectory. This article aims to explore the relationship between extension and transfer of knowledge from the analysis of international influences in brazilian university extension. The literature on extension in Brazil recognizes two international influences extension in practice in the country: the European Popular Universities and Land Grant Colleges US. To these two influences sum up the reform movement of Cordoba as a mark of origin of the extension in Brazil. Initially the three international influences on university extension in Brazil and how the idea of knowledge transfer appears in each of them initially are addressed. Then it presents the criticism of the idea of knowledge transfer from two authors reference for the Brazilian university extension: Paulo Freire and Michel Thiollent. Finally, the last section, we analyze the three influences in the face of criticism of the idea of knowledge transfer. The results suggest that the European and US influences are grounded in the perspective of knowledge transfer. The Latin American Popular Universities, in turn, seem to point to the criticism of the university and for overcoming an extension that promotes a guardianship relationship between the university and the popular classes.

Key words: University extension. Knowledge transfer. Reform of Cordoba. 


\section{Introdução}

A ideia de transferência de conhecimento sempre esteve presente na relação entre universidade e sociedade. A noção de que a universidade deveria oferecer às classes populares o conhecimento que produzia está na origem do termo extensão e segue presente em toda a sua trajetória histórica.

A ideia central é sempre a mesma: de que as classes populares, ao terem acesso ao conhecimento, poderiam superar as mazelas que enfrentam. Ela se apresenta a partir de diferentes expressões como ilustrar as massas, expor a ciência ao povo, difusão cultural, utilizar o conhecimento produzido pela universidade, socialização da cultura, difusão do saber acadêmico, elevar o nível de cultura geral do povo, homogeneização cultural, levar os saberes ao povo, levar a universidade à classe dominada, elevação do nível cultural do povo preparandoo para a vida e para o trabalho, estender a universidade à comunidade, estender à comunidade a atividade de ensino e o resultado da pesquisa, integração cultural, estender a universidade ou o conhecimento à sociedade, transmissão do saber, transmissão de conhecimento ${ }^{1}$. A extensão seria, assim, um processo educativo de transferência do conhecimento produzido pela universidade às pessoas que a ela não tiveram acesso. Distribuir conhecimento, nessa perspectiva, seria a maneira pela qual a universidade poderia contribuir com a melhoria das condições de vida das classes populares.

O debate sobre a extensão nas universidades brasileiras encontra raízes nas origens da extensão universitária. Alguns autores atribuem a origem do termo 'extensão' à Inglaterra ${ }^{2}$ do século XIX (PAIVA, 1974; FAGUNDES, 1986; CARNEIRO, 1985). Nessa época, a universidade inglesa, no contexto da Revolução Industrial, é forçada a diversificar sua atuação dando origem à extensão como atividade institucional (FAGUNDES, 1986). Paiva (1974) afirma que ela surge com objetivo de difundir a cultura e oferecer oportunidades de educação continuada à população adulta que não se encontrava na universidade enquanto Carneiro (1985) afirma que a extensão é produto da Revolução Industrial inglesa e tinha como fundamento a educação de adultos operários fora da jornada de trabalho.

Para além da origem inglesa do termo, a literatura sobre extensão universitária no Brasil aponta duas influências para a compreensão da prática extensionista no país: as Universidades Populares europeias e os Land Grant Colleges dos EUA. A essas duas influências, este artigo soma à história da extensão, as ideias sintetizadas no Manifesto de Córdoba como marco na origem da extensão no Brasil. Nesse sentido, parte-se de três e não apenas duas influências: europeia, estadunidense e latino-americana. Para isso, contudo, foi necessário ir além da

\footnotetext{
${ }^{1}$ Essas expressões foram coletadas na revisão bibliográfica realizada na literatura brasileira sobre extensão.

${ }^{2}$ Embora seja consenso na literatura o surgimento do termo extensão na Inglaterra, há registros de atividades semelhantes que não receberam essa denominação em outros lugares do mundo. Um exemplo são as experiências no Canadá, nas universidades de Alberta e de St Francis Xavier, no início do século XX. São experiências universitárias com comunidades de pescadores e suas famílias, com mineiros de carvão e siderúrgicos, nas quais eram promovidas reuniões de massa e grupos de estudo para debater os problemas da comunidade e aprender através de ação econômica em sociedades de crédito e cooperativas (PEERS, 1972, p. 267 apud IRELAND, 2002).
} 
literatura sobre a extensão universitária e buscar referências à extensão na literatura sobre o movimento reformista de Córdoba.

Este artigo tem como objetivo explorar a relação entre extensão e transferência de conhecimento a partir das influências internacionais na extensão universitária brasileira e da crítica feita por dois autores centrais na literatura sobre extensão no país: Paulo Freire e Michel Thiollent. Com esse intuito, inicialmente são abordadas as três influências internacionais na extensão universitária no Brasil e a maneira como a ideia de transferência de conhecimento aparece em cada uma delas. Em seguida, aborda-se a crítica à ideia de transferência de conhecimento a partir de dois autores referência teórica-metodológica para a extensão universitária brasileira: Paulo Freire e Michel Thiollent. Por fim, na última seção, à guisa de conclusão, analisa-se as três influências diante da crítica à ideia de transferência de conhecimento.

\section{As influências internacionais na extensão universitária brasileira}

Uma das maneiras de contar a história da extensão no Brasil é através de suas influências históricas. Tradicionalmente, a literatura aponta para duas principais vertentes: as Universidades Populares europeias e o modelo extensionista dos EUA de prestação de serviço (GURGEL, 1986; NOGUEIRA, 2005).

Um dos marcos iniciais da história da extensão foi a criação das chamadas Universidades Populares (UP). Existentes em diversos países, inclusive na América Latina, as UPs surgiram a partir do descontentamento daqueles que estavam nas universidades, mas também daqueles que estavam fora dela, reivindicando o acesso que lhes era negado. Nesse período, a extensão se resumia a cursos livres, abertos à população em geral, com temas variados.

As Universidades Populares surgem no século XIX na Europa a partir do esforço autônomo de intelectuais, com uma clara intenção de ilustrar as populações que não tinham acesso à universidade. Outras expressões utilizadas para caracterizar a ação na época foi 'conscientizar as massas' e 'aumento do nível cultural do povo' (GURGEL, 1986). Thiollent (1998) se refere às experiências de UP na França nos anos 1960 e afirma que em 1968 houve outra onda de UPs na França, influenciada pelas experiências prévias na Alemanha.

A ideia da UP na Europa era tida como um meio provisório para desenvolver uma atividade externa sem compromisso com o sistema universitário e que manifestava a vontade dos universitários de se colocar a serviço da classe trabalhadora a partir de relações pedagógicas não convencionais. Ainda assim, eram experiências reconhecidas, com docentes profissionais expondo a ciência ao povo. Para Botomé (1996) as UPs europeias tinham como finalidade colocar a população em contato com o conhecimento produzido na universidade. Por essa característica foram criticadas por Antonio Gramsci por serem marcadas pela ausência de uma relação orgânica com os trabalhadores (THIOLLENT, 1998).

No Brasil, a influência das UPs foi sentida em diversos momentos, sendo o primeiro deles na Universidade Livre de São Paulo, criada em 1912, tida como a primeira experiência de extensão no país. A Universidade Livre de São Paulo, uma escola particular, foi fundada em 1911 (GURGEL, 1986). O projeto incluía as escolas superiores de direito, engenharia, farmácia, medicina, odontologia, comércio e belas artes. Essa experiência, contudo, teve curta 
duração, tendo sido fechada em 1917 com a negativa do Conselho Federal de Educação em mantê-la em funcionamento (MOTT; DUARTE; GOMES, 2007). No entanto, não era a universidade em si a atividade pioneira de extensão, mas sim os cursos populares gratuitos, a Associação Beneficente Universitária (Instituto Luiz Pereira Barreto - Hospital de Caridade do Braz) e a Academia de Ciências.

Importante ressaltar que essa a experiência não surge como reivindicação da massa marginalizada, mas sim a partir do "ato de vontade ou 'idealismo' de segmentos da comunidade acadêmica universitária" (FAGUNDES, 1986, p. 41). Em consonância com essa visão, Tavares (1997) classifica essas experiências como voltadas para os interesses da própria academia e não das classes populares.

Uma das principais críticas aos cursos livres eram os temas ministrados, pois, na maioria das vezes, eram escolhidos pelos próprios professores envolvidos. Por outro lado, aqueles que ministravam os cursos, reclamavam da baixa participação nos mesmos. Gurgel (1986) afirma que a experiência era mal compreendida ou ignorada pelas classes populares. A observação desse autor, somada às características da experiência, coloca em destaque a forte presença, na Universidade Livre de São Paulo, da ideia de transferência de conhecimento presente nas UPs europeias caracterizadas anteriormente. E, com isso, na extensão dessa época os intelectuais "mesmo desejosos de servir ao povo [...] expressavam [...] uma visão dominadora de seus saberes ao pretender 'levá-los' ao povo" (MELO NETO, 2002, p. 8).

A segunda influência a ser considerada na história da extensão no Brasil foram os Land Grant Colleges nos EUA que partiam da extensão como prestação de serviço e se organizavam a partir da ideia de desenvolvimento comunitário, a autonomia e voluntariado (CARNEIRO, 1985).

Segundo Singer (2001), as universidades dos EUA, por terem características distintas das europeias, não hesitavam em atender demandas dos governos e das empresas, pois "precisavam provar sua utilidade e mostrar que mereciam apoio ao iniciar novos cursos de estudo e pesquisa, bem como ao 'vender' adequadamente seus serviços" (BEN-DAVID, 1971, p. 213 apud SINGER, 2001).

A partir da influência estadunidense, se consolida no Brasil a ideia de extensão como prestação de serviço (GURGEL, 1986) que tem como fundamento o forte caráter modernizador, a regionalização das universidades (quando os cursos oferecidos como extensão se tornavam permanentes nas regiões atendidas) e a ideia de utilização do conhecimento produzido na universidade (BOTOMÉ, 1996).

No Brasil, o primeiro marco dessa influência para a extensão é a criação da Escola Superior de Agricultura Veterinária de Viçosa, em 1926. Vinculado à extensão rural $^{3}$, o modelo implementado tinha como foco a assistência técnica aos agricultores. A extensão rural, por sua vez desde seu surgimento teve a função de

veicular, entre os agricultores, a ideia de que a forma com que produziam e viviam era atrasada e responsável pelos baixos rendimentos por eles obtidos e pela consequente dificuldade de viver do trabalho da terra. A solução seria portanto, substituí-las por técnicas modernas, utilizan-

3 Mais informações sobre a temática da extensão rural em Bergamasco (1992) e Pettan (2010). 
do o crédito para consumir produtos industrializados e, com isso, produzir mais e, desse modo, viver melhor (MASSELLI, 1998, p. 34).

Nessa perspectiva, é inevitável a conexão do modelo implementado e da influência dos EUA com um caráter modernizador baseado na ideia de transferência de conhecimento.

A influência dos EUA também esteve presente na Reforma Francisco Campos, em 1931, na qual houve forte influência dos chamados Pioneiros, participantes do movimento Escola Nova. Foi nela também que o ministro do recém-criado Ministério da Educação e da Saúde, Francisco Campos, dentre outras determinações, cria o Estatuto das Universidades Brasileiras.

Analisando a Reforma Francisco Campos, Fagundes (1986) chama atenção para o fato de a universidade ser compreendida como uma instituição que produz uma cultura superior que não está a alcance de todos e que é marcadamente superior à cultura veiculada pelo povo. $\mathrm{O}$ autor evidencia a ideia de transferência de conhecimento afirmando que a extensão seria uma ação de homogeneização cultural "tendo em vista diluir nas diferenças culturais as desigualdades sociais ao nível da apropriação dos bens produzidos coletivamente” (p. 48). Já o Estatuto das Universidades Brasileiras, no qual, pela primeira vez na legislação, é utilizada a palavra extensão, é considerado o "principal veículo de difusão da formulação extensionista da prestação de serviços técnicos gerais, numa perspectiva mais ampla" (GURGEL, 1986, p. $65)$.

A influência dos EUA nas universidades brasileiras é sentida ainda mais forte na década de 1950. Com os acordos entre o Ministério da Educação (MEC) e a United States Agency for Internacional Development (USAID) ${ }^{4}$, o modelo extensionista estadunidense se torna premissa do reconhecimento da extensão pelo Estado brasileiro, processo levado a cabo pelo então recém-criado Conselho de Reitores das Universidades Brasileiras (CRUB).

As duas influências na extensão universitária no Brasil apresentadas, no entanto, não devem ser as únicas a serem consideradas. Além das Universidades Populares europeias e dos Land Grant Colleges dos EUA, será abordada a seguir uma terceira vertente da extensão: a influência latino-americana.

\section{A influência latino-americana - o movimento reformista de Córdoba}

Ainda que na literatura sobre extensão universitária no país sejam poucas e esparsas as referências às Universidades Populares latino-americanas e ao movimento reformista de Córdoba, na Argentina, e ainda que a origem das Universidades Populares seja atribuída à Europa, as experiências latino-americanas adquirem contornos e características próprias (MARIÁTEGUI, 1975; BERNHEIN, 1978 apud GURGEL, 1986).

Na América Latina, com diferenças significativas em relação à experiência europeia, diversas UPs surgiram na mesma época. As experiências como a Universidade Popular Mexicana (1912), a Universidade Popular Lastarria (1918) no Chile, as Universidades Populares

\footnotetext{
${ }^{4}$ A intensificação da influência dos EUA nesse período não se restringe à extensão e pode ser sentida desde a década de 1950 através dos acordos MEC/USAID que "financia e promove no Brasil, tanto o treinamento de torturadores, como a reforma da universidade" (RIBEIRO apud GURGEL, 1986, p. 76).
} 
González Prada (1922) no Peru e a Universidade Popular José Martí ${ }^{5}$ (1923) em Cuba mostram algumas das características particulares da experiência latino-americana.

Sobre a UP peruana, Portantiero (1978) afirma que a mesma era gerida pelos estudantes e que todas as resoluções deviam ser ratificadas em assembleia geral. $\mathrm{O}$ autor também afirma que o lema da experiência era "la universidad popular no tiene otro dogma que la justícia social" (p. 79). Além disso, as Universidades Populares latino-americanas têm como característica central a aliança trabalhador-estudante como destaca González (apud CALDELARI, 2003, p. 39).

\begin{abstract}
Desde o primeiro momento, o trabalhador esteve ao lado do estudante, encorajando-o com sua presença, apoiando-o com suas armas de luta. Em seguida esta aproximação se tornou uma íntima vinculação. Os grêmios iam à greve para ajudar a campanha dos estudantes e os últimos faziam o mesmo com os trabalhadores, entrando como em sua casa nos locais de trabalho dos proletários.
\end{abstract}

A aliança estudante-trabalhador é uma questão recorrente nas experiências latinoamericanas e marca um momento na história de muita contestação. Inspirados pela Reforma de Córdoba (1918), os intelectuais ligados às Universidades Populares eram também os líderes estudantis que lutavam com os operários, com destaque para José Carlos Mariátegui e Haya de la Torre, no Peru, e José Mella ${ }^{6}$ em Cuba (NOVAES, 2012, p. 200). Segundo Portantiero (1978), essas diversas experiências darão origem ao marxismo latino-americano e, especificamente, Haya de la Torre e outros estudantes no Peru são os responsáveis por construir o primeiro partido nacional-popular do continente. Ainda sobre as Universidades Populares, Mariátegui (1975) afirma que elas surgiram no calor da Reforma da Córdoba e que elas se tornaram realidade em toda a América Latina.

Segundo Bernheim (apud GURGEL, 1986, p. 36), é a partir do movimento reformista de Córdoba que a missão social da universidade passou a constar efetivamente no discurso oficial e nas propostas da universidade. Nessa perspectiva, essa experiência contribui para a conformação da identidade da universidade latino-americana que assume a extensão como um dos seus componentes.

O livro de Juan Carlos Portantiero, de 1978, nos ajuda a entender o ocorrido na Universidade Nacional de Córdoba naquele ano a partir da perspectiva de ação dos estudantes. $\mathrm{O}$ autor situa a faísca da renovação na mobilização estudantil principalmente contra o sistema de provisão de cátedras na época. Das assembleias dos diretórios de medicina e engenharia sai a decisão de entrar em greve se as autoridades não atendessem suas reivindicações. Posteriormente o diretório de Direito se une aos outros dois e surge o Comitê Pró-reforma. As autoridades ignoram a mobilização estudantil e os alunos fazem a primeira de muitas grandes marchas que realizariam daí em diante. Nesse período, os estudantes estavam de férias e, na volta

\footnotetext{
${ }^{5}$ Essa universidade popular foi fechada em 1927 considerada um perigoso foco comunista. Segundo Novaes (2012), ela era dirigida pelos trabalhadores.

${ }^{6}$ Mella disse que os estudantes deveriam "hermanarse los hombres de trabajo para fomentar una nueva sociedad libre de parásitos y tiranos, donde nadie viva sino en virtud del próprio esfuerzo" (PORTANTIERO, 1978, p. 65).
} 
às aulas, nem um só aluno compareceu. A partir daí, se inicia uma longa trajetória de negociação entre alunos e docentes, com algumas intervenções do governo federal a favor dos alunos. Houve a aceitação da intervenção na universidade e na reforma do seu estatuto, mas a participação dos estudantes no governo da universidade não foi aceita.

A movimento teve três fases: na primeira, havia uma aliança entre estudantes, jovens professores e graduados liberais. Já na segunda, houve eleição dos decanos com contundente influência externa dos estudantes. Na terceira etapa, há eleição para reitor na universidade e o candidato apoiado pelos estudantes é derrotado. Inicia-se, então, o momento culminante do movimento, no qual a débil aliança entre estudantes e professores é rompida. Surge então a percepção, por parte dos estudantes, que os professores eram incapazes de propiciar uma mudança radical na vida universitária, o que desencadeia a consigna da gestão tripartite (professores, estudantes e graduados) e paritária. Após um violento episódio, os estudantes novamente declaram greve geral e convocam os estudantes argentinos a se mobilizarem.

Nesse período surge o apoio de sindicatos e partidos de esquerda e se torna evidente o ideário latino-americano do movimento uma vez que:

hacia fines de julio de 1918 el movimiento estudantil había llegado a dar pasos impensados meses antes: controlaba la movilización callejera, había organizado federaciones em todas las universidades, realizado un congresso nacional y elaborado un completo plan de reformas a la organización interna de la enseñanza superior (PORTANTIERO, 1978, p. 49).

Os estudantes, com marchas de mais de vinte mil pessoas, ocupam a universidade e assumem o governo da mesma, nomeando professores e elegendo os decanos. No dia da inauguração dos cursos, são retirados pelo exército e todos os estudantes são presos. No entanto, em 1921, "la reforma universitaria rige em todas las casas de estudio de la Argentina: cogobierno estudantil, docencia libre, asistencia libre de los alumnos a clase, 'la democracia universitária"' (PORTANTIERO, 1978, p. 55). Pouco tempo depois, com a sucessão presidencial, há intervenção nas universidades e revogação dos estatutos reformistas. Com o governo ditatorial em 1930 a mobilização é sufocada e o movimento estudantil, fortemente reprimido.

Ainda assim, os ecos de Córdoba não demoraram a chegar a outros países, expressando em pouco tempo o 'destino americano' que os estudantes haviam intuído para a reforma universitária. Inicialmente uma onda sacudiu Peru, Chile e mais tarde Cuba, Colômbia, Guatemala e Uruguai e, logo depois, nos anos 1930, uma segunda onda chega ao Brasil, Paraguai, Bolívia, Equador, Venezuela e México (PORTANTIERO, 1978).

No Brasil, em 1938, já no seu segundo congresso, a recém-criada União Nacional dos Estudantes (UNE), lança uma proposta funcional em relação ao ensino, à pesquisa e à extensão. Sobre esta propõe a criação de cursos de extensão e de Universidades Populares inspiradas nos princípios do movimento de Córdoba (GURGEL, 1986). Concomitantemente, surgem os comitês democráticos ${ }^{7}$ em periferias de grandes cidades que trabalhavam com Educação de

\footnotetext{
7 Essas atividades duraram apenas dois anos, no período de legalidade do Partido Comunista Brasileiro (PCB) responsável pela criação desses comitês. Em 1947 o partido é fechado e os comitês democráticos, extintos.
} 
Jovens e Adultos (EJA), educação popular, agremiações esportivas, grupos de debate, peças teatrais, etc e a Universidade do Povo no Distrito Federal ${ }^{8}$ (GÓES, 1980).

Os ecos do movimento reformista também podem ser sentidos no período considerado mais fértil da extensão universitária brasileira. No início da década de 1960, o movimento estudantil brasileiro, assim como em diversas regiões do mundo, assumiu um papel contestatório do papel da universidade. A extensão praticada pelos estudantes nesse período "é o primeiro aceno de mudança na sua concepção. É quando se veem ações concretas na direção do compromisso com as classes populares, não de forma assistencial, mas com intencionalidade de conscientizá-las sobre seus direitos" (NOGUEIRA, 2005, p. 26-27).

Nessa mesma época, o então ministro da educação Darcy Ribeiro se empenha em fazer um diagnóstico da educação no país e divulgar os dados trágicos sobre o tema ${ }^{9}$. Diante da realidade constatada, especialmente, da imensa população analfabeta, "o equacionamento da solução jamais poderia ser o acadêmico, o clássico, o conservador” (GÓES, 1980, p. 65).

Na contramão das aspirações da época, em 1961, foi promulgada a Lei de Diretrizes e Base da Educação Nacional (LDB) que se mostrou avessa à mudança e à reformulação da educação superior no país, tendo sida avaliada negativamente por não ter grandes novidades e até alguns retrocessos. Também em 1961, vem à tona a Declaração da Bahia (1961) e, posteriormente, a Carta do Paraná $(1962)^{10}$, dois importantes documentos do período que, como resume Gurgel (1986), comparando-os com a prática da época, continham diretrizes que já eram executadas pelas universidades e por outras organizações, mas não de maneira globalizante como são apresentadas, com ênfase na extensão. $O$ autor conclui que "a universidade da Declaração da Bahia era a universidade da extensão" (p. 50). Essa universidade da extensão proclamada pelos estudantes era "uma trincheira de defesa das reivindicações populares, através da atuação política da classe universitária na defesa de reivindicações operárias, participando de questões junto aos poderes públicos e possibilitando cobertura aos movimentos de massa" (SOUZA, 2000, p. 38).

A influência do movimento reformista de Córdoba nesse período é bastante marcante. Souza (2000) afirma que a relação estudante-trabalhador, presente nas UPs latino-americanas, marca o movimento estudantil na região até os dias de hoje ${ }^{11}$. Wanderley (1984) resume a atuação discente argumentando que eles retomaram os pontos centrais da Reforma de Córdoba. No entanto, esse período é, assim como na Argentina, brutalmente interrompido e a reação

\footnotetext{
${ }^{8} \mathrm{O}$ antigo Distrito Federal é hoje a atual cidade do Rio de Janeiro.

9 Segundo uma reportagem da revista Veja da época "De acordo com os números oficiais, apenas quatro entre cada dez crianças com idades entre 7 e 11 anos estão matriculadas nas escolas. Pior: a metade desse contingente está cursando apenas a primeira série do ensino primário. Entre todos os alunos que iniciam sua formação no País, só $21,4 \%$ chegam à segunda série (19,3\% avançam à terceira e 14,1\% à quarta). No ensino secundário, a situação é de arrepiar. Apenas nove entre cada cem jovens brasileiros conseguem alcançar esse nível. Por fim, há o desastre do analfabetismo. Conforme levantamentos recentes, o Brasil tem o pior índice de alfabetização de toda a América Latina, superando até seu vizinho mais pobre, a Bolívia. Calcula-se que o País abrigue um exército de 5,8 milhões de iletrados, o equivalente a $39 \%$ de toda a população nacional". (A PÁTRIA..., 1962).

10 Documentos elaborados como resultado do I e II Seminário Nacional da Reforma Universitária promovido pela UNE, respectivamente.

11 Para uma discussão atual no Brasil sobre as Universidades Populares, ver Caribé (2008).
} 
proporcional à radicalidade dos estudantes. Após o golpe militar de 1964 essas experiências extensionistas sofreram uma verdadeira caça às bruxas ${ }^{12}$.

O início dos anos 1960 , e outros na história da extensão ${ }^{13}$, foi um período de muita força e criatividade da prática extensionista. Nesses momentos, é evidente que a extensão é acompanhada por uma luta pela democracia no país e na universidade, se aproximando da luta travada pelo movimento reformista de Córdoba. São momentos que reivindicam não apenas a possibilidade de praticar a extensão e de se aproximar das classes populares, mas também e, principalmente, postulam a necessidade da transformação da sociedade. Nessa perspectiva, a universidade, seja por meio dos estudantes, seja por meio dos docentes, almeja uma sociedade menos desigual e mais democrática.

Cabe pontuar a diferença entre as três influências em relação à transferência de conhecimento. Se por um lado as Universidades Populares europeias buscavam transferir o conhecimento para a população em geral, ilustrando as massas, por outro, os Land Grand Colleges buscavam utilidade para os conhecimentos produzidos pela universidade através da assessoria técnica aos agricultores, isto é, da prestação de serviços. Ainda assim, em ambas perspectivas, não se tratava de reformar a universidade, mas de estendê-la às pessoas que a ela não tinham acesso. As Universidades Populares latino-americanas, por sua vez, partem de uma profunda crise das universidades e da busca por reformá-las, por torná-las mais democráticas internamente e, externamente, através do fortalecimento da aliança trabalhador-estudante. $\mathrm{O}$ fato de os estudantes e de as classes populares serem consideradas sujeitos na reforma das universidades e da transformação da sociedade difere essa influência das outras duas, uma vez que a transferência de conhecimento pressupõe um receptor passivo, como será abordado na próxima seção.

Em suma, pode-se afirmar que tanto as experiências de Universidades Populares europeias como as experiências estadunidenses tinham como fundamento a transferência de conhecimento. Já na América Latina, as experiências tiveram maior caráter contestatório e de aproximação com as lutas operárias, do que a busca por 'ilustrar as massas'. Como diferencial, partiam da ideia das classes populares como sujeito ativo, e não passivo, na relação entre universidade e sociedade.

\section{Críticas à ideia de transferência de conhecimento}

A ideia de transferência de conhecimento é recorrente na trajetória da extensão. A crença de que a universidade possui um conhecimento superior e que sua mera extensão geraria melhoria nas condições de vida da população em geral não é uma questão ultrapassada.

12 Um exemplo é o Teatro da UNE que foi inaugurado e demolido no dia seguinte sem nunca ter sido estreado. O mesmo autor fala sobre o fim violento que teve a campanha 'De pés no chão também se aprende a ler' com a prefeitura invadida, o prefeito preso, 83 pessoas indiciadas e muitos presos, entre eles professores e estudantes (GÓES, 1980). Outro exemplo de extrema violência foi a invasão e fechamento da faculdade de Filosofia e Letras da USP (SANTOS, 1988). A UNE foi extinta no mesmo ano. Souza (2000) afirma que o prédio da UNE foi incendiado e os documentos do CPC destruídos.

13 A exemplo do período de democratização, com o fim da ditadura militar, e da atuação docente através do Fórum Nacional de Pró-Reitores de Extensão das Universidades Públicas Brasileiras (Forproex). 
Em alguns momentos de maneira muito sutil e, em outros, explicitamente, a extensão carrega essa ideia mais como fundamento do que como crítica.

É com o educador Paulo Freire, em sua obra 'Extensão ou Comunicação' de 1969 que a crítica à ideia de estender a universidade ou o conhecimento à sociedade se consolida na literatura sobre extensão universitária. Freire (1983) afirma que o termo extensão se encontra em relação significativa com transmissão, entrega, doação, messianismo, mecanicismo, superioridade (do conteúdo de quem entrega), inferioridade (dos que recebem), invasão cultural, etc. A invasão cultural, segundo o educador, se da "através do conteúdo levado, que reflete a visão do mundo daqueles que levam, que se superpõe à daqueles que passivamente recebem" (FREIRE, 1983, p. 13). E completa "não nos é possível ignorar a conotação ostensiva da invasão cultural que há no termo extensão" (p. 28) ainda mais se considerarmos, nas palavras do autor, os condicionamentos histórico-sociológicos do conhecimento. Por isso,

\footnotetext{
todos esses termos envolvem ações que, transformando o homem em quase 'coisa', o negam como um ser de transformação do mundo. Além de negar [...] a formação e constituição do conhecimento autêntico. Além de negar a ação e a reflexão verdadeiras àqueles que são objetos de tais ações. [...] Desta análise depreende, claramente, que o conceito de extensão não corresponde a um que-fazer educativo libertador (FREIRE, 1983, p. 13).
}

Paulo Freire nega a ideia de transferência de conhecimento e qualifica a ação de um extensionista que transfere conhecimento como uma ação que nega o outro como 'ser de transformação do mundo', isto é, parte da ideia do 'objeto' da transferência de conhecimento como alguém incapaz de transformar sua própria realidade.

Freire (1983) ainda afirma que "quando se tem uma opção libertadora [...], aos homens se lhes problematiza sua situação concreta, objetiva, real, para que, captando-a criticamente, atuem também criticamente, sobre ela" (p. 14). Argumenta que "a 'educação como prática da liberdade' não é a transferência ou a transmissão do saber nem da cultura; não é a extensão de conhecimentos técnicos; não é o ato de depositar informes ou fatos nos educandos; não é a perpetuação dos valores de uma cultura dada"' (p. 53).

Entretanto a contribuição de Paulo Freire vai além desse livro. A prática de Paulo Freire se dá a partir da universidade, como atividade de extensão. Paulo Freire participou do Movimento de Cultura Popular (MCP) e foi nele que levou a cabo suas primeiras experiências com educação de adultos através dos círculos de cultura. O MCP foi criado em 1960 pela Prefeitura de Recife e desde sua fundação já se preocupava com "modos de transcender a característica de doação de bens culturais [...] como produtos acabados" (GÓES, 1980, p. 49). Segundo Gurgel (1986), o MCP surge de uma iniciativa institucional da Universidade e leva a cabo uma das experiências mais ricas de alfabetização de adultos. O MCP era uma experiência que trabalhava com a ideia de Universidade Popular e com a valorização empírica da cultura popular (SOUZA, 2000). Paulo Rosas afirma que se lembra "dos círculos de cultura com a emoção de quem pensa em sua universidade de utopia" (ROSAS apud FREIRE, 2006, p. 132). 
Após dois anos de atuação, Paulo Freire sai do MCP para se dedicar ao Serviço de Extensão Cultural (SEC) da Universidade de Recife ${ }^{14}$. Seguiu, portanto, a trilha da extensão fazendo um convênio entre a universidade e o governo do estado do Rio Grande do Norte para atuação na cidade de Angicos.

Paulo Freire marca a história da extensão, pois, embora tenha havido diversas experiências contestatórias, até então não havia uma crítica amplamente aceita que colocasse em xeque a ideia de transferência de conhecimento como fundamento da extensão. Da contribuição de Paulo Freire, duas ideias centrais merecem destaque: a invasão cultural e a passividade do sujeito que recebe o conhecimento. A partir da primeira, decorrem dois argumentos fundantes da transferência de conhecimento: a) a ação de estender conhecimentos estende também normas e valores, isto é, visão de mundo; e b) considera-se que tanto conhecimento quanto a visão de mundo de quem transfere são superiores aos de quem recebe. A segunda ideia, a passividade do sujeito, ou como denomina o autor, do objeto da transferência de conhecimento, decorre da negação do outro enquanto sujeito capaz de transformar sua própria realidade.

Michel Thiollent é outro autor que traz elementos relevantes para o debate proposto neste artigo. Embora seja mais conhecido por suas reflexões sobre a pesquisa-ação, o autor tem contribuído com o tema da metodologia de extensão, inclusive se envolvendo com o Seminário de Metodologias para Projetos de Extensão (SEMPE), existente desde 1996.

$\mathrm{O}$ autor franco-brasileiro traz como inspiração as experiências que teve em maio de 1968, em Paris, especialmente, o seu envolvimento com uma experiência de Universidade Popular e as possibilidades de repensar a universidade naquele contexto. Segundo Thiollent (1998), o ensino e a pesquisa foram fortemente questionados durante aquele período, mas essa face de maio de 68 foi esquecida por colocar em risco a manutenção do establishment acadêmico. Segundo o autor, entre outras contestações, estava presente a denúncia da falsa neutralidade e da falsa objetividade do saber. Também dessa época, as críticas no campo da Educação já evidenciavam "que era necessário superar qualquer didática centrada na transmissão de um conhecimento preestabelecido" (THIOLLENT, 1998, p. 73).

Em seu texto 'Construção do conhecimento e metodologia da extensão', de 2002, encontramos referências diretas do autor sobre a transferência do conhecimento no processo educativo da extensão. A crítica de Thiollent (2002) à transferência de conhecimento parte do entendimento deste como uma construção social e da extensão, assim como a pesquisa, como uma construção de conhecimento que envolve, além dos universitários, atores com culturas, interesses e níveis de educação diferentes. O autor também afirma que a extensão não deve ser entendida como "uma simples divulgação de informação destinada a um público composto de 'receptores' individualizados e passivos" (THIOLLENT, 2002, p. 2).

Para ele, esse entendimento da extensão parte de uma ideia equivocada de que o conhecimento poderia ser primeiro produzido e depois difundido. Thiollent defende que, ao levar em consideração a construção social do conhecimento, os projetos de extensão se tornarão

${ }_{14}$ Atualmente Universidade Federal de Pernambuco (UFPE). 
mais adequado aos objetivos de transformação social a que se propõem. Entre outros argumentos, afirma que o conhecimento necessário para os projetos de extensão é "compartilhado entre atores com visões e habilidades diferenciadas que tornariam inoperante a transferência de cima para baixo" (p. 3).

Além disso, o conhecimento requerido pela extensão seria co-construído e deveria passar pelo crivo da "reflexão-na-ação". Thiollent desenvolve essa ideia a partir do conceito de reflexividade de Donald Schön e afirma que um projeto de extensão reflexivo ajudaria seus "destinatários a refletirem na ação; assim eles são incitados a construir um conhecimento próprio. Bons projetos de extensão são aqueles que geram ganhos de conhecimento e de experiência para todos os participantes, com base no ciclo relacionando ação e reflexão" (THIOLLENT, 2002, p. 7).

A extensão, para o autor, é compreendida como uma ação educativa que, quando tem um propósito emancipatório, se torna um desafio às leis de reprodução social e gera transformações sociais a partir do acesso das camadas populares à educação, "não apenas acesso ao vigente conhecimento elitizado, mas, sobretudo, à condição de construir conhecimentos novos, em termos de conteúdos, formas e usos" (THIOLLENT, 2002, p. 8).

Thiollent (1984, p. 45) afirma que

a concepção prevalecente da difusão é essencialmente 'recepcionista'. Os usuários são simples 'receptores' de informação acerca das técnicas e estão mais ou menos dispostos a aceitá-las. Não se imagina um esforço de criação de técnicas e de mobilização coletiva em torno de práticas adequadas à situação dos produtores. Pressupõe-se que a técnica é sempre 'importada' pelo grupo 'receptor'. Não há interesse particular na geração interna de ideias, técnicas ou em modos de difusão dotados de relativos graus de autonomia.

Em suma, Michel Thiollent destaca alguns aspectos da extensão que relacionam metodologia e conhecimento, dando ênfase para construção social do mesmo, a sua não neutralidade e a inadequação do processo de transferência quando os projetos educativos envolvidos buscam a emancipação das classes populares e a transformação social.

$\mathrm{O}$ autor reforça a ideia de que a transferência de conhecimento é um processo inoperante que parte de uma visão do 'receptor' como um sujeito passivo. Em oposição a essa ideia, propõe um processo de produção do conhecimento que valide este em um ciclo que relacione ação e reflexão das pessoas envolvidas. Essa proposta, em consonância com outros autores, aponta para uma democratização da produção do conhecimento e para o reconhecimento das classes populares como sujeitos do processo de produção de conhecimento.

Em suma, pode-se afirmar que há dois elementos fundantes, e complementares, para compreender a crítica à ideia de transferência de conhecimento. O primeiro deles é reconhecer que o conhecimento produzido e armazenado nas universidades, isto é, sob a égide do método científico, não é o único conhecimento existente, válido e legítimo. Já o segundo, parte do entendimento da ciência como uma construção social que não trilha um caminho linear e inexorável e nem intrinsecamente positivo e que, portanto, é permeada e marcada pelas contradições existentes na sociedade. 


\section{Considerações Finais}

A história da extensão nos mostra que os momentos criativos e combativos da extensão são momentos seguidos por uma reação conservadora, as vezes bastante violenta, e assistencialista, gerando desmobilização e apatia ${ }^{15}$. Por isso, essa trajetória parece apontar sempre para uma resistência e, logo em seguida, para a contenção da resistência inserida em uma disputa de projetos políticos de universidade e/ou de sociedade (FRAGA, 2012). Por isso, parece uma difícil tarefa responder a pergunta se extensão universitária tem sido capaz de agregar as forças progressistas da universidade em busca de uma sociedade menos desigual e mais democrática.

Demo (2001) caracteriza a extensão como extrínseca, voluntária, acessória e afirma que ela seria "a má consciência da universidade, em duplo sentido: de uma parte, porque, incomodada com a pecha de 'torre de marfim', inventa vinculações sociais compensatórias e, de outra, porque não consegue trazer o desafio social [...] para dentro da proposta curricular" (DEMO, 2001, p. 141). O autor argumenta que a extensão deveria ser inserida no ensino e na pesquisa, pois "a dedicação social precisa também reverter-se em capacidade de lidar com o conhecimento" (DEMO, 2001, p. 154). Ao que parece, a pesquisa e o ensino estão blindados em relação aos projetos alternativos de universidade e de sociedade.

A universidade, de maneira geral, sempre esteve voltada para os interesses das elites. Isso não significa que não haja outros projetos em disputa, mas sim que esses outros projetos sempre estiveram subjugados a um projeto hegemônico. E é desse ponto de vista que a extensão deve ser compreendida: como um espelho que reflete as contradições da sociedade e que atua nelas também. Disso decorre a compreensão da extensão como contentora dos ânimos progressistas, mas também como espaço histórico de resistência e disputa. É nesse contexto que está inserida a ideia de transferência de conhecimento.

Ao mesmo tempo em que se considera que a extensão forma parte do consenso ideológico e cultural "de socialización, que cumplía el sistema educativo, em virtud de la cual los indivíduos internalizam el esquema de valores y de normas que em última instância consolida y legitima, a nivel subjetivo, el sistema social imperante" (BERNHEIM, 2001, p. 39), os períodos pré-1964 e de redemocratização do país apontam para o questionamento da ideia de transferência de conhecimento a partir da extensão. Além disso, os momentos subsequentes, a ditadura militar e o governo FHC, atuaram esvaziando esses questionamentos e despolitizando a extensão (FRAGA, 2012). Do que é possível inferir que a crítica à ideia de transferência de conhecimento se acentua em momentos de maior radicalidade da atuação contrahegemônica da universidade.

15 Alguns momentos que podem ser lembrados é o processo de institucionalização da extensão durante o governo militar principalmente através do Projeto Rondon e o Projeto Universidade Solidária durante o governo Fernando Henrique Cardoso, que tinha como coordenadora a então primeira-dama, Ruth Cardoso (FRAGA, 2012). 
Na literatura sobre extensão no Brasil, a relação das classes populares com a universidade indica a manutenção dessa ideia. A primeira armadilha da ideia de transferência de conhecimento está no fato de as classes populares serem correntemente consideradas como público alvo (e as vezes até como clientes) e não como sujeitos ativos da extensão. Essa ausência reforça a ideia de transferência de conhecimento, uma vez que caracteriza o 'receptor' de conhecimento como um sujeito passivo que recebe os benefícios gerados pela atuação da universidade. A ideia de transferência de conhecimento se apresenta como uma armadilha, isto é, como uma ideia (e uma prática) autoritária dentro de perspectivas progressistas da extensão.

A segunda armadilha é considerar que a Universidade possui o conhecimento acumulado pela humanidade ou, pelo menos, todo conhecimento relevante e legítimo. É bem verdade que gerar e acumular conhecimento é uma de suas funções, mas a universidade lida com um tipo de conhecimento: o conhecimento científico. Por outro lado, ela pouco sabe sobre os saberes tradicional, comunitário, popular ou sobre a ciência do povo que, a partir de outros métodos, produz e acumula conhecimento (FALS BORDA, 2009).

A terceira armadilha, decorrente da anterior, é acreditar que existe um conhecimento neutro, objetivo, fora das contradições da sociedade. A visão que se tem do conhecimento é um divisor de águas no qual, de um lado estão aqueles e aquelas que percebem a não neutralidade do conhecimento e que, por isso, são capazes de propiciar espaços ${ }^{16}$ de negociação entre diferentes saberes para que a voz das classes populares se materialize nas soluções encontradas, no conhecimento inevitavelmente produzido nesse processo e, inclusive, na formulação do problema a ser enfrentado. Do outro lado, estão aqueles que, tendo como fundamento a ideia de que o que falta aos trabalhadores é a capacitação, transferem conhecimentos, ignorando essa negociação e levando a cabo a invasão cultural de que falava Paulo Freire e, mantêm uma relação de tutela entre universidade e classes populares.

Fugir dessas armadilhas é condição para aqueles e aquelas que, a partir da universidade, se propõem a buscar uma sociedade menos desigual e mais democrática. O que falta às classes populares é acesso a direitos, inclusive, de produzir conhecimento e de ter seus saberes legitimados. A conclusão a que se chega a partir das reflexões deste artigo, contudo, não leva a ideia de que a academia não deva socializar os conhecimentos historicamente acumulados na universidade. Essa socialização, no entanto, deve partir do pressuposto que esses conhecimentos podem e precisam ser questionados e transformados.

Em um primeiro momento, se faz necessário reconhecer que as influências europeias e estadunidense reforçam a ideia de transferência de conhecimento e que, em alguma medida, desviaram a extensão universitária brasileira de seu 'destino americano', como afirmava o movimento reformista de Córdoba. A perspectiva das universidades populares latino-americanas, por sua vez, parece apontar para a autocrítica da universidade e para a superação de uma extensão autoritária, assistencialista e que fomenta uma relação de tutela da universidade com as classes populares. Nessa perspectiva, a extensão universitária brasileira em busca de uma so-

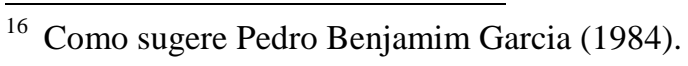


ciedade menos desigual e mais democrática, tenderia a se aproximar das reflexões da Reforma de Córdoba e dos seus ecos em toda América Latina.

\section{Referências}

BERGAMASCO, Sônia M. P. P. Extensão Rural. In: CORTEZ, L. A. B.; MAGALHÃES, P. S. G. (Org.). Introdução à engenharia agrícola. Campinas: Ed. UNICAMP, 1992. v. 1, p. 353-363

BERNHEIM, Carlos Tünnermann. El nuevo concepto de extensión universitaria. In: FARIA, Doris Santos de. Construção conceitual da extensão universitária na América Latina. Brasília: UnB 2001. p. 31-55.

BOTOMÉ, Sílvio Paulo. Pesquisa alienada e ensino alienante: o equívoco da extensão brasileira. Petrópolis: Vozes, 1996.

CALDELARI, María. Apuntes sobre extensión universitaria en la UBA: 1955-1966. In: KROTSCH, Pedro. La universidad cautiva: legados, marcas y horizontes. La Plata: Al Margen, 2003. p. 43-56.

CARIBÉ, Daniel. Ensaio para uma universidade popular. Cadernos do CEAS, Salvador, v. 229, p. 10-25, 2008.

CARNEIRO, Moaci Alves. Extensão universitária: versões e perversões: estudo tentativo de identificação do débito social das universidades federais do nordeste. Rio de Janeiro: Presença Edições, 1985.

DEMO, Pedro. Lugar da extensão. In: FARIA, Doris Santos de. Construção conceitual da extensão universitária na América Latina. Brasília: UnB, 2001. p. 141-158.

FAGUNDES, José. Universidade e compromisso social. Campinas: Ed. Unicamp, 1986.

FALS BORDA, Orlando. Uma sociologia sentipensante para América Latina: antología y presentación de Vístor Manuel Moncayo. Bogotá: Siglo Del Hombre Editores y CLACSO, 2009.

FRAGA, Lais Silveira. Extensão e transferência de conhecimento: as incubadoras tecnológicas de Cooperativas Populares. 2012. 242 p. Tese (Doutorado) - Instituto de Geociências, Universidade Estadual de Campinas, Campinas, SP. Disponível em: <http://www.bibliotecadigital.unicamp.br/document/?code=000903143>. Acesso em: 23 dez. 2015.

FREIRE, Ana Maria Araújo. Paulo Freire: uma história de vida. Indaiatuba: Villa das Letras, 2006.

FREIRE, Paulo. Extensão ou comunicação? 7. ed. Rio de Janeiro: Paz e Terra, 1983.

GARCIA, Pedro Benjamim. Educação popular: algumas reflexões em torno da questão do saber. In: BRANDÃO, C. R. (Org.). A questão política da educação popular. 4. ed. São Paulo: Brasiliense, 1984. p. 88-121.

GÓES, Moacyr de. De pé no chão também se aprende a ler (1961-1964): uma escola democrática. Rio de Janeiro: Ed. Brasileira, 1980. 
GURGEL, Roberto Mauro. Extensão universitária: comunicação ou domesticação. São Paulo: Cortez; Autores Associados; UFC, 1986.

IRELAND, Thimoty Denis. Educação de jovens e adultos e extensão universitária: primos pobres? Aproximações para um estudo sobre a educação de jovens e adultos na universidade. In: MELO NETO, José Francisco de. Extensão universitária: diálogos populares. João Pessoa: Ed. UFPB, 2002.

MARIÁTEGUI, José Carlos. Sete ensaios de interpretação da realidade peruana. São Paulo: Alfa-Omega, 1975.

MASSELLI, Maria Cecilia. Extensão rural entre os sem-terra. Piracicaba: Ed. Unicamp, 1998.

MELO NETO, José Francisco. Extensão universitária: bases ontológicas. In: MELO NETO, José Francisco (Org.). Extensão universitária: diálogos populares. João Pessoa: Ed. UFP, 2002. p. 13 - 33.

MOTT, Maria Lucia; DUARTE, Ivomar Gomes, GOMES, Marcela Trigueiro. Montando um quebra-cabeça: a coleção " Universidade de São Paulo" do Arquivo Público do Estado de São Paulo. Caderno de História da Ciência, São Paulo, v. 3, n. 2, p. 37-72, 2007.

NOGUEIRA, Maria Das Dores Pimentel. Políticas de extensão universitária brasileira. Belo Horizonte: Ed. UFMG, 2005.

NOVAES, Henrique T. Reatando um fio rompido: a relação universidade-movimentos sociais na América Latina. São Paulo: Expressão Popular, 2012.

PAIVA, Vanilda. Extensión universitaria en Brasil. Nueva Sociedad, San Jose, Costa Rica, n. 15, p.68-83, dez. 1974.

A PÁTRIA dos iletrados. Veja, São Paulo, out. 1962. Disponível em: Disponível em: $<$ http://origin.veja.abril.com.br/historia/crise-dos-misseis/brasil-educacao-analfabetos-darcyribeiro.shtml>. Acesso em: 13 de maio de 2017.

PETTAN, Kleber Batista. A política nacional de assistência técnica e extensão rural (PNATER): percepções e tendências. Tese (doutorado) - Faculdade de Engenharia Agrícola, Universidade Estadual de Campinas, Campinas, 2010.

PORTANTIERO, Juan Carlos. Estudiantes y política en América Latina (1918-1938): el proceso de la reforma universitária. México-DF: Siglo Veintiuno, 1978.

SANTOS, Maria Cecília Loschiavo do (Org.). Maria Antônia: uma rua na contramão. São Paulo: Nobel, 1988.

SINGER, Paul. A universidade no olho do furacão. Estudos Avançados, São Paulo, v. 15, n. 42, p. 305-316, 2001.

SOUZA, Ana Luiza Lima de. A história da extensão universitária. Campinas: Alínea, 2000.

TAVARES, Maria das Graças M. Extensão universitária: novo paradigma de universidade. Maceió: Edufal, 1997.

THIOLLENT, Michel J. M. Anotações críticas sobre difusão de tecnologia e ideologia da modernização. Cadernos de Difusão de Tecnologia, Brasília, v. 1, n. 1, p. 43-51, 1984. 
THIOLLENT, Michel. Maio de 1968 em Paris: testemunho de um estudante. Tempo Social, São Paulo, v. 10, n. 2, p. 63-100, out. 1998.

THIOLLENT, Michel J. M. Construção do conhecimento e metodologia da extensão. ICBEU, 2002.

WANDERLEY, Luiz Eduardo. O que é universidade? 2. ed. Brasília: Brasiliense, 1984. 